\title{
Effects of Foliar Application of Organic Fertilizer "Disper Alghum" And Growth Regulator Kt-30on Vegetative Growth, Flowering and Fruit Set
}

\author{
N. F. Abd-Allatif ${ }^{-1}$, I. M. H. Al.Bayati ${ }^{-2}$ \\ ${ }^{1}$ Researcher.Dep. of Horticulture, College of Agriculture, University of Baghdad, Iraq. \\ ${ }^{2}$ Assistant prof. Dep. of Horticulture, College of Agriculture, University of Baghdad, Iraq.
}

\begin{abstract}
A factorial experiment within randomized complete block design (RCBD)during the growing season 2016-2017 was carried to investigate the influence of foliar application organic fertilizer "DisperAlghum" and growth regulator KT-30 on vegetative growth, flowering , fruit set on two years old "Anna" apple transplant, the transplants was sprayed with organic fertilizer "DisperAlghum" $(D)$ at three levels $\left(0,3,5 \mathrm{~g} . \mathrm{L}^{-1}\right)$, and growth regulator $K T-30(K)$ at four levels $\left(0,5,10,20 \mathrm{mg} \cdot \mathrm{L}^{-1}\right)$, the foliar application of organic fertilizer $D_{5}$ $\left(5 \mathrm{~g} . \mathrm{L}^{-1}\right)$ gave significantly higher values of the length branches vegetative of $115.7 \mathrm{~cm}$, leaf area of $6.383 \mathrm{~cm}^{2}$, leaves number of 11230 leave.transplant ${ }^{-1}$, total leaves area of $726 \mathrm{Dcm}^{2}$, main stem diameter of $19.99 \mathrm{Mm}$, leaves dry weight of $46.67 \%$, percentage of inflorescences to vegetative buds of $7.74 \%$, percentage of fruit set of $88.24 \%$, while there are non-significant value in branches number for all levels. The foliar application of growth regulator $K_{20}\left(20 \mathrm{mg} . \mathrm{L}^{-1}\right)$ gave significantly higher values of the length branches vegetative of $117.8 \mathrm{~cm}$, branches number of 168.4 branch.plant ${ }^{-1}$, leaf area $5.852 \mathrm{~cm}^{2}$, leaves number of 9067 leaves.transplant ${ }^{-1}$, total leaves area of $568 \mathrm{Dcm}^{2}$, leaves dry weight of $48.65 \%$, percentage of inflorescences to vegetative buds of 7.40 $\%$, percentage of fruit set of $88.45 \%$, whileK $10\left(10 \mathrm{mg} . \mathrm{L}^{-1}\right)$ significantly Increase the main stem diameter of $20.84 \mathrm{Mm}$. The interaction treatment $D_{5} K_{20}$ significant increased leaf area, leaves number; total leaves area, percentage of inflorescences to vegetative buds.
\end{abstract}

\section{Introduction}

Apple (MalusDomesticaBorkh) is an important member of family Rosaceae native to Central and West Asia and requires hours of cold enough to break the dormancy of its buds, Among the varieties that are widely cultivated in the temperate and cold areas, Anna is characterized by its low coldness (300-400) hours, less than $7.2^{\circ} \mathrm{C}$, characterized by large size and elongation, with 30-40\% red color, ripening Fruits at the end of June and the beginning of July (Crocker at el , 2004). Many studies have shown that spraying on fruit tree leaves gives a clear increase in vegetative growth to make the most of these nutrients, especially at times when trees can't get enough nutrients (Kemira, 2004 and Taiz and Zeiger , 2010). Organic acids such as humic acid have an effect on plant growth. It acts on nutrienttransfer within the plant and stimulates plant growth. Seaweed extract is widely used as an organic product and is a growth promoter for containing organic and amino acids, plant hormones, vitamins, minerals and others. (Sangha at el, 2014) It was noted that when used, it improves vegetative growth and is environmentally friendly and does not cause environmental damage (Battacharyya at el, 2015). Cytokinins like plant growth regulators that plays an important role in the cell, affecting multiple plant functions, promoting chlorophyll's bio-building, cell division and elongation, and increasing flowering and fruit set.The target of this study was to evaluate vegetative growth and fruit set of "Anna" apple cultivar under using DisperAlghumand KT-30under Iraq conditions.

\section{Materials And Methods}

This study was conducted in college of Agriculture - Baghdad University during the growing season 2016-2017 to investigate the influence of foliar application organic fertilizer "DisperAlghum" and growth regulator KT-30 ( CPPU ) on vegetative growth, flowering, fruit set, of apple transplantc.v "Anna" 2 years oldcultivation in orchard, dimensions $2.5 \times \mathrm{X}$, where applied factorial experiment with two treatments and three replicates were applied in randomized complete block design (RCBD) the first factor "DisperAlghum" was three levels ( D ) $\left(0,3,5\right.$ g.L $\left.\mathrm{L}^{-1}\right)$, the second factor KT-30 ( CPPU ) was four levels ( K ) $\left(0,5,10,20 \mathrm{mg} . \mathrm{L}^{-}\right.$ ${ }^{1}$ ), was taken one tree in each experimental unit ,The total number becomes 36 transplants.DisperAlghum contains 59\% Humic Acid, Fulvic Acid 14\%, Seaweed Extract 10\%, K2O 14\%, while Growth Regulator KT-30 (CPPU) 99\% pure.The spraying procedure was done at sunset until full wetness at 3 pitches per treatment. The period between spray and other 15 days and between the regulators 48 hours, and was added with the spray solution of the material Tween-20 (0.2) to reduce the surface tension, The spraying process was carried out one day after irrigating the young trees. The data were analyzed on the Genstate program and the mean was 
compared using the least significant difference of L.S.D at the probability level of 0.05 (Al-Rawi and Khalafalla , 2000) .

1- Vegetative branches length $(\mathrm{cm})$

The lengths of modern vegetative growths were measured by empirical metric at the end of November. Ten branches were randomly selected for each structural branch and for all experimental units.

\section{2-Vegetative branches Number (branch.transplant ${ }^{-1}$ )}

The number of modern growing branches per transplant was calculated during the month of November.

3- Leaf area $\left(\mathrm{cm}^{2}\right)$

The area of the leaf was calculated in June by way of the disks, known as the area and the wet and dry weight, where 10 leaves were taken from the fourth leaf to the seventh leaf under the developing summit and dried with the electric furnace. The weight was then calculated according to the equation according to (Wien , 1997).

4- LeavesNumber (leaves.transplant ${ }^{-1}$ )

The number of leaves per transplants was calculated in June, where a structural branch was selected and the leaves were calculated and the number was multiplied by the number of structural branches of the tree.

5-Total leaves area $\left(\mathrm{Dcm}^{2}\right)$

After calculating the area of the paper by $\left(\mathrm{cm}^{2}\right)$ was calculated by $\left(\mathrm{Dcm}^{2}\right)$ :-

Total leaf area $\left(\mathrm{Dcm}^{2}\right)=\left(\right.$ area of leaf $\left(\mathrm{cm}^{2}\right) /$ number $) \mathrm{x}$ total number of leaves $/ 100$

Note that 100 conversion coefficients from $\left(\mathrm{cm}^{2}\right)$ to $\left(\mathrm{Dcm}^{2}\right)$.

6-Increase in stem diameter $(\mathrm{mm})$

Stem diameter were measured by (Vernier) at the beginning In April (at the beginning of the experiment), and was measured in October (the end of the experiment), according to the difference between them and that such an increase in stem diameter.

7-Leaf dry weight (\%)

In June, taken 10 leaves were from the fourth leaf to the seventh under the developing summit in different directions from each sapling, then washed with distilled water to remove the dust and left to dry the air by putting it on the waste paper to get rid of the washing water. Then removed the necks and weighed with a sensitive digital balance and samples were placed in bags Paper was perforated in an oven at $65^{\circ} \mathrm{C}$ until the weight was stable (dry sample), then weighed by a sensitive digital balance and the percentage of dry weight was calculated to moderate (Al-Sahaf, 1989).

8-percentage of inflorescences to vegetative buds $(\%)$

In the month (12 March) for the year 2017 was calculated of inflorescences to vegetative buds according to the following equation:

Number of flowering flowers=Number of inflorescences/ Number ofvegetative budsx100

9-percentage of fruit set $(\%)$

After two weeks of full bloom was calculated on (27 March) for the year 2017 through the following equation:-

Fruit set $=$ Number of fermented fruits $/$ Number of Flowers $\mathrm{x} 100$

\section{Results And Discussions}

Effect of DisperAlghum" andGrowth Regulator KT-30 on vegetative growth:Concerning the Results in Table (1)vegetative branches length, vegetative branchesnumber, leaf area, leaves number, total leaves area, stem diameter,leaves dry weight weresignificantly affected by all treatments, spraying trees withDisperAlghumat 5 g.L $\mathrm{L}^{-1}$ and KT-30 at $20 \mathrm{mg} . \mathrm{L}^{-1}$ gave the best Results.

Table (1): Effects of foliar application of organic fertilizer "DisperAlghum" and growth regulator KT-30on vegetative growth.

\begin{tabular}{|c|c|c|c|c|c|c|c|}
\hline treatment & $\begin{array}{c}\text { vegetative } \\
\text { branches } \\
\text { length }(\mathrm{cm})\end{array}$ & $\begin{array}{c}\text { vegetative branches } \\
\text { number (branch.plant }{ }^{-1} \text { ) }\end{array}$ & $\begin{array}{l}\text { leaf area } \\
\left(\mathrm{cm}^{2}\right)\end{array}$ & $\begin{array}{c}\text { Leavesnumber } \\
\text { (leave. } \\
\text { Transplants }^{-1} \text { ) }\end{array}$ & $\begin{array}{l}\text { Total leaves } \\
\text { area }\left(\mathrm{Dcm}^{2}\right)\end{array}$ & $\begin{array}{c}\text { stem } \\
\text { diameter } \\
(\mathrm{mm})\end{array}$ & $\begin{array}{l}\text { Leaves dry } \\
\text { weight }(\%)\end{array}$ \\
\hline $\mathbf{D}_{0}$ & 110.4 & 138.5 & 4.469 & 3997 & 181 & 18.77 & 44.94 \\
\hline $\mathbf{D}_{3}$ & 107.4 & 115.8 & 5.270 & 7153 & 379 & 19.42 & 46.24 \\
\hline$D_{5}$ & 115.7 & 145.7 & 6.383 & 11230 & 726 & 20.00 & 46.67 \\
\hline L.S.D 5\% & 1.714 & N.S & 0.314 & 87.2 & 30.38 & 0.644 & 0.602 \\
\hline $\mathbf{K}_{0}$ & 107.7 & 108.9 & 4.943 & 6142 & 324 & 16.11 & 44.27 \\
\hline $\mathbf{K}_{5}$ & 108.1 & 129.2 & 5.207 & 7034 & 384 & 20.49 & 45.23 \\
\hline$K_{10}$ & 111.0 & 126.9 & 5.494 & 7597 & 438 & 20.84 & 45.65 \\
\hline$K_{20}$ & 117.9 & 168.4 & 5.852 & 9067 & 568 & 20.15 & 48.65 \\
\hline L.S.D 5\% & 1.979 & 19.59 & 0.363 & 100.7 & 35.08 & 0.744 & 0.695 \\
\hline $\mathbf{D}_{0} \mathrm{~K}_{0}$ & 116.7 & 130.6 & 3.929 & 2927 & 115 & 14.59 & 43.73 \\
\hline$D_{0} K_{5}$ & 95.6 & 183.8 & 4.374 & 3795 & 165 & 23.06 & 43.97 \\
\hline $\mathrm{D}_{0} \mathrm{~K}_{10}$ & 105.6 & 83 & 4.748 & 4248 & 202 & 19.53 & 44.90 \\
\hline $\mathrm{D}_{0} \mathrm{~K}_{20}$ & 123.7 & 156.6 & 4.826 & 5017 & 241 & 17.88 & 47.17 \\
\hline
\end{tabular}


Effects Of Foliar Application Of Organic Fertilizer "Disper Alghum" And Growth Regulator Kt-30on

\begin{tabular}{|c|c|c|c|c|c|c|c|}
\hline $\mathbf{D}_{3} \mathbf{K}_{\mathbf{0}}$ & 89.7 & 79.4 & 5.105 & 6035 & 309 & 14.03 & 44.64 \\
\hline $\mathbf{D}_{\mathbf{3}} \mathbf{K}_{\mathbf{5}}$ & 115.9 & 65.3 & 5.204 & 6896 & 359 & 20.95 & 45.04 \\
\hline $\mathbf{D}_{\mathbf{3}} \mathbf{K}_{10}$ & 113.7 & 124.3 & 5.318 & 7338 & 391 & 25.69 & 45.59 \\
\hline$D_{3} K_{20}$ & 110.4 & 194.3 & 5.451 & 8341 & 455 & 17.02 & 49.68 \\
\hline $\mathbf{D}_{5} \mathrm{~K}_{\mathbf{0}}$ & 116.8 & 116.6 & 5.794 & 9463 & 548 & 19.70 & 44.43 \\
\hline $\mathrm{D}_{5} \mathrm{~K}_{5}$ & 112.8 & 138.6 & 6.044 & 10412 & 629 & 17.46 & 46.69 \\
\hline$D_{5} K_{10}$ & 113.6 & 173.3 & 6.415 & 11204 & 720 & 17.29 & 46.47 \\
\hline $\mathbf{D}_{5} \mathbf{K}_{20}$ & 119.5 & 154.3 & 7.278 & 13842 & 1007 & 25.54 & 49.09 \\
\hline L.S.D 5\% & 3.428 & 33.93 & 0.629 & 174.4 & 60.76 & 1.289 & 1.204 \\
\hline
\end{tabular}

This may be due to the positive effect of the seaweed extract as it reduces the effect of growth inhibitors and stimulates plant vegetative growth because it contains many nutrients (major and minor), enzymes, amino acids and plant hormones ofAuxins, Cytokininand Gibberellin that stimulate cell division, Responsible for the activity of alfalfa and plant movements and to prolong the life of the cells, which affect extensively on the vital activities of food production and the accumulation of quantities of wood and bark in the diameters (O,Dell , 2003 , Spinelli at el , 2009 , Osman , 2010) This explains the increase in vegetative growth and compatibility (Al-Gumaely , 2016 and Thanaa at el 2016) Cytokinineis responsible for cell division, differentiation and elongation. It encourages the formation of shoots on growing vegetative growths on transplant and increasing the number of leaves by increasing the opening of lateral buds and the development of chloroplasts and chlorophyll biosynthesis through a course on the physiological processes responsible for those The increase in Photosynthesis, breathing and nutrient transfer from root to leaf increases the area of vegetative growths and delays their aging. This explains the increase in vegetative growth (Gundea , 2003 , Zeng , 2016 and Zhang , 2013) and These results are in agreement with those obtained by(Bhat , 2011 and Al-Karam , 2016)

\section{Effect of DisperAlghum" and Growth Regulator KT-30 on Flowers and fruit set:}

Concerning the Results in Table (2) percentage of inflorescences to vegetative buds,percentage of fruit setwere significantly affected by all treatments, spraying trees with DisperAlghum at 5 g.L. $\mathrm{L}^{-1}$ and KT-30 at 20 mg.L ${ }^{-1}$ gave the best Results .

Table (2): Effects of foliar application of organic fertilizer "DisperAlghum" and growth regulator KT-30on Flowers and fruit set

\begin{tabular}{|c|c|c|}
\hline Treatment & $\begin{array}{c}\text { Percentage of inflorescences to vegetative buds } \\
(\%)\end{array}$ & Fruit set (\%) \\
\hline $\mathrm{D}_{0}$ & 5.48 & 83.70 \\
\hline $\mathbf{D}_{3}$ & 6.59 & 87.18 \\
\hline$D_{5}$ & 7.74 & 88.24 \\
\hline L.S.D 5\% & 0.535 & 1.217 \\
\hline$K_{0}$ & 5.37 & 84.09 \\
\hline $\mathbf{K}_{5}$ & 6.44 & 86.07 \\
\hline $\mathbf{K}_{10}$ & 7.21 & 86.88 \\
\hline$K_{20}$ & 7.40 & 88.45 \\
\hline L.S.D 5\% & 0.618 & 1.405 \\
\hline $\mathbf{D}_{0} \mathbf{K}_{0}$ & 5.21 & 78.32 \\
\hline $\mathrm{D}_{0} \mathrm{~K}_{5}$ & 5.30 & 81.66 \\
\hline $\mathrm{D}_{0} \mathrm{~K}_{10}$ & 5.08 & 90.27 \\
\hline $\mathrm{D}_{0} \mathrm{~K}_{20}$ & 6.34 & 84.56 \\
\hline $\mathbf{D}_{3} \mathbf{K}_{0}$ & 5.01 & 88.11 \\
\hline$D_{3} K_{5}$ & 6.01 & 85.44 \\
\hline $\mathbf{D}_{3} K_{10}$ & 8.79 & 83.14 \\
\hline $\mathbf{D}_{3} \mathbf{K}_{20}$ & 6.54 & 92.02 \\
\hline $\mathrm{D}_{5} \mathrm{~K}_{0}$ & 5.89 & 85.85 \\
\hline $\mathbf{D}_{5} \mathrm{~K}_{5}$ & 8.00 & 91.10 \\
\hline$D_{5} K_{10}$ & 7.75 & 87.24 \\
\hline $\mathbf{D}_{5} \mathbf{K}_{20}$ & 9.32 & 88.76 \\
\hline L.S.D 5\% & 1.07 & 2.434 \\
\hline
\end{tabular}

The status of flowering and fruit set has increased the impact of organic fertilizer spray probably due to the content of the extract of the major elements and micro which there are ready to be absorbed as nitrogen works to increase the effectiveness of carbon representation which increases the food factory, which supplies its flowering buds and flowers, as included in the installation nucleic acids ,Proteins and amino acids necessary to build hormones that regulate the vital processes of amino acids, as well as in the formation of acid enters Polyamine, which appeared that it plays a role in urging an important organizational flowering, as well as its role in the manufacture of hormones andLikeauxins ,Cytokininorganized a Vital processes in the plant and encourage the growth of flowering buds, the role of potassium in the formation of amino acids that stimulate the 
enzyme formation IAAoxidase, which in turn stimulates the induction of syphilis, which is required in osmosis regulation and activation of enzymatic and transport operations in the membranes (Vernieri at el 2006 , Connell , 2012 andScherer and Mengel , 2007), which is reflected in the increase in the number of flowers and the proportion of the contract table (2) is also compatible with what he found (Fatma at el , 2015 and Khan at el 2012). It has been found that cytokanine stimulates the formation of flowers in trees falling leaves that require cold hours until sprouts sprout and grow, as it shortens the length of rest in the buds and begins to mature by increasing the level of cytokinin and increase the contract of fruits through the expansion of ovaries and adjacent tissues, Tumor and ovulation tubes may be attributed to increased DNA and RNA levels and protein As well as the gathering of food in the parts treated with cytokinin, and works to convert some male flowers to female flowers in plants that carry male and female flowers on the same plant (Al-Khafaji , 2014), this explains the increase in the number of flowers and the proportion of the contract as in the table (Al-Karam , 2016) and These results are in agreement with those obtained by (Asaad, 2014 and Shahin at el , 2010 ).

\section{References}

[1] Al-Gumaely, O. G. M .2016. Effect of Foliar Application of Plant Growth Regulator Brassinolide and Seaweed Extract on Vegetative Growth and Yield of "Anna" Apple Tree. M .Sc. Thesis Collage of Agriculture. Al-Anbar Univ .pp73.

[2] Al-Karam, B.N.I.2016. Effect Foliar Application of Organic Fertilizer and Growth Promoter on Growth of Woolly Peach sapling "Red June" M.Sc. Thesis Collage of Agriculture .Baghdad Univ. pp 64 .

[3] Al- Khafaji , M.A .2014. Plant Growth Regulator, Application and Utilization in Horticulture. Ministry of High Education and Scientific Research. University of Baghdad/ College of Agriculture. p 5-7.

[4] Al-Rawi, K.M. and A.M. Khalafalla .2000. Design and Analysis of Agricultural Experiments. Ministry Of High Education and Scientific Research Mosul Univ .pp.270.

[5] Al-Sahaf, F. H. 1989. Applied Plant Nutrition. Ministry of Higher Education and Scientific Research. Baghdad University. Bayt Al Hikma. Iraq. pp 260 .

[6] Asaad ,Samia A .2014. The in fluence of spraying sitofox (CPPU), iron , manganese and zinc on " anna " apple trees planted on new reclaimed calcareous land - life science jonrnal $2014 ; 11$ (1s) - hort - res . institute , abc , egypt - http : // wwwi life sciencencesite . com .

[7] Battacharyya ,Redhriti . Babgohari ,Mahboba , Zamani . Rathor ,Pramod . Prithivirj ,Balakrishnan .2015. Seaweed extracts asbiostimulant inhorticultur . science direct scientiahorticulturae journal homepage online:www.elsevier.com/locate/scihculti .

[8] Bhat ,Zahoor Ahmad .; Rashid ,Rizwan .; Bhat ,Javid Ahmad . (2011). Effect of plant growth regulators on leaf number, leaf area and leaf dry matter in grape. Not Sci Biol 3 (1): $87-90$.

[9] Connell ,Ucd .2012. Nutritional recommendations for olive .official magazine of the international olive council . booklet .P : 1-83 .

[10] Crocker T.F., W.B. Shermn and J.G. Williaman .2004. The Apple . Horticultural Sciences Department, Florida ExtentionService , Institute of Food and Agricultural Sciences, University Of Florida Gainsville FL32611 .pp 116

[11] Fatma, K. M .S .Morsey, M . M .Thanaa .S .M . M .2015. Influence of spraying yest extract and humic acied on fruit maturity stag and storability of "canion" apricot fruits .internationl journal of chentech research 8 (6) : $530-543$.

[12] Gundea , Hasan .2003. Physiology Fruit Trees . Frist Edition .AldarArabea for Publishing and Distribution .The Egyption Arabic Government . p 245

[13] Kemira,G.H .2004. Application of Micronutrients :Pros and Cons The Different Application Strategies -IFA International Sympiosinm on Micronutrients.Internet/International Fertilizer Industry Association .23-25 February 2004 . New Delhi, India .

[14] Khan, A . S ., B . Ahmad, M .J . Jaskani , R. Ahmad And A .U . Malik .2012. Foliar application of mixture of amino acids and seaweed (ascophylum nodosum) extract improve growth and physico-chemical properties of grapes .Int .J .Agric .Biol . , 14 : 383 388 .

[15] Moghadam , H . R .T ., M . K .Khamene, H . Zahedi .2014. Effect of humic acid foliar application on growth and quantity of corn in irrigation withholding at different growth stages .maydica . 59; 124-128 .

[16] O,Dell , C . 2003. Natural plant hormones are biostimulants helping plants develop high plant antioxidant activity for multiple benefits .virginia vegetables, smallfruit and special crops novcmber 2003, volume2 ,ISSUE 6 . P.132-141.

[17] Osman , S . M .2010. Effect of mineral, Bio-NPK soil application of young olive trees and foliar fertilization on leaf and shoot chemical composition. Research journal of agriculture and biological science, 6(3):311-318 .

[18] Sangha, Jatinder Singh. Kelloway, Stephen . Critchley, Alan, T. Prithiviraj, Balakrishnam . 2014. Chapter seven .seaweed (macroagae) and their extracts as contributors of plant productivity and quality. Vol .71:189-219.

[19] Scherer , H . W .and K . Mengel .2007. Ullmann's Agro Chemicals . Fertilizers .Vol .3 Wiley-VchVerlagGmbh\& Co , Kgaa , Weinheim (Chapter 2).

[20] Shahin, M.F.M., M.L.F. Fawzi and E.A. Kandil .2010. Influence of folier application of some nutrient (fertiformisr) and gibbreellic acid on fruitset, yield, fruit quality and leaf composition of "Anna" apple trees grown in sandy soil . Journal of american science. 6(12) 202-208.

[21] Spinelli , F.; G . Fiori ; M . Noferini ; M . Sprocatti and G .Costa . 2009. Perspectives on the use of a seaweed extract to moderate the negative effects of alternate bearing in apple trees .J .ofHort . Sci .\&Biotech .17(1): 131-137 .

[22] Taiz .L .and E . Zeiger .2010. Plant Physiology . 5th Ed .SinauerAsseciates .Inc . Publisher Sunderland ,Massachus-Ahs . U.S.A.

[23] Thanaa S. M. , K.M. Fatma., M M. Morsey and Y. El-Nagger .2016. Study on the effect of pre - harvest treatment by seaweed extract and amino acid on " Anna " apple growth, leaf mineral content, yield, fruit quality at harvest and stroability. International, Journal of ChemTechRessarch . 9 (5) 161-171.

[24] Vernieri, P ., Borghesi , E ., Tognoni , F., Serra , G ., Ferrante , A . And Piagessi, A .2006. Use of Bio-Stimulants for reducing nutrient solution concentration in floating system. Acta horticulturae , 718: 477-484.

[25] Wien, H . C .1997. The Physiology Of Vegetable Crops . The Univ . Press Cambridge , UK . Pp .662 .

[26] Zeng, Hui . Yang, Weihai . Lu Chaozhong .Lin ,Wenqiu . Zou ,Minghong . Zhzng, Hanzhou . Wan ,Jifeng . Huang ,Xuming .2016. Effect of CPPU on carbohydrate and endogenous hormone levels in young macadamia frout .Plos one 11(17) : E 0158705 . Doi: 10 1371 / journal .Pone .0158705 .

[27] Zhang,Caixi and Whiting Matthew .2013. Plant growth regulators improve sweecharry fruit quality without reducing endocarp growth . Scientia horticulturae, 150 , complete, 73-79. 